\title{
Article \\ Effect of Aluminum on Microstructure and Mechanical Properties of Weld Metal of Q960 Steel
}

\author{
Zongxuan Zou, Zhengjun Liu *, Xingyu Ai and Dan Wu \\ Department of Materials Science and Engineering, Shenyang University of Technology, Shenyang 110870, China; \\ 15942492610@163.com (Z.Z.); 18809816959@163.com (X.A.); axy544043201@sina.com (D.W.) \\ * Correspondence: liuzhengjun1962@163.com; Tel.: +86-138-0499-4179
}

check for updates

Citation: Zou, Z.; Liu, Z.; Ai, X.; Wu, D. Effect of Aluminum on

Microstructure and Mechanical

Properties of Weld Metal of Q960

Steel. Crystals 2022, 12, 26. https://

doi.org/10.3390/cryst12010026

Academic Editors: José L. García and Indrajit Charit

Received: 17 November 2021

Accepted: 21 December 2021

Published: 24 December 2021

Publisher's Note: MDPI stays neutral with regard to jurisdictional claims in published maps and institutional affiliations.

Copyright: (c) 2021 by the authors. Licensee MDPI, Basel, Switzerland. This article is an open access article distributed under the terms and conditions of the Creative Commons Attribution (CC BY) license (https:// creativecommons.org/licenses/by/ $4.0 /)$.

\begin{abstract}
High-strength low-alloy (HSLA) steel is used in important steel structural members because of its strength and plastic toughness. Q960 steel is HSLA steel obtained by adding an appropriate amount of alloy elements and quenching and tempering treatment on the basis of ordinary lowcarbon steel. This kind of steel has strong hardenability due to the alloy elements added. Cold cracks, embrittlement and softening of the heat-affected zone easily occur after welding. In particular, the low-temperature impact toughness cannot meet the requirements and limits its use. In this paper, self-shielded welding is used to adjust the content of aluminum in flux-cored wire. The relationship between weld metal (WM) microstructure and strength and properties was studied by tensile test and impact test, and the influence mechanism of $\mathrm{Al}$ content on weld metal microstructure and properties was analyzed. The results show that when the content of $\mathrm{Al}$ is $0.21 \%$, the impact energy at $0{ }^{\circ} \mathrm{C} \sim-60^{\circ} \mathrm{C}$ is the best, the tensile strength can reach $1035 \mathrm{MPA}$ and the number of pores is small. The size of inclusions in WM is mostly less than $1.0 \mu \mathrm{m} \mathrm{Al}_{2} \mathrm{O}_{3}$ spherical oxide. It can become the center of acicular ferrite (AF) and increase the nucleation probability. However, with the increase of $\mathrm{Al}$ content, large irregular AIN inclusions are produced, which reduces the tensile strength and impact energy of the welded joint.
\end{abstract}

Keywords: low-alloy high-strength steel; flux-cored wire; acicular ferrite; inclusion

\section{Introduction}

HSLA steel is used in pipeline transportation, bridge, shipbuilding, offshore platform, mining machinery and other important industries because of its strength and plasticity, corrosion resistance, fatigue resistance and other advantages [1]. However, it is difficult to assure the impact toughness of this kind of steel during welding, especially the lowimpact toughness, which restricts the use of this kind of steel in a wider range at low temperature [2,3]. As a new welding material, flux-cored wire (FCW) has the advantages of easy adjustment of composition, good weld formation and easy operation [4]. In particular, it can reasonably mix the composition of flux core for different base metals to make it more targeted and improve the quality of joint. It has replaced traditional welding materials such as welding rod and welding wire and has been widely used in various industries.

Weld alloying is a common way to ameliorate the strength and toughness of WM of HSLA steel [5]. Adding Ti, V and Nb to the WM shows similar microstructure. However, it has high tensile strength, and ameliorates the low-temperature impact toughness of the weld to varying degrees [6]. This is due to the formation of fine precipitates containing Ti, $\mathrm{V}$ and $\mathrm{Nb}$. These precipitates can become nucleation particles of $\mathrm{AF}$ in grains and promote formation [7-10]. When there is a large amount of AF in the WM structure of high-strength steel, good impact toughness will be obtained [11]. The reason is that AF is a lath with a certain aspect ratio formed in the original austenite grain. The large-angle grain boundaries between the lath are interlaced with each other, so that the material is subjected to great resistance when fracture and expansion occur, showing excellent impact toughness [12]. 
Moreover, the AF has a subcrystalline structure and high-density dislocations, so the strength of WM is improved [13].

S. D. Bhole et al. found that the increase of molybdenum content promoted the formation of microstructure of welding metal dominated by ferrite, and its toughness was significantly improved. Adding $0.881 \mathrm{wt} \%$ to the $\mathrm{WM}$ molybdenum has the best impact toughness at $-45^{\circ} \mathrm{C}$ [14]. Gang Huang et al. found that a small amount of nickel had a significant effect on M-A composition and AF formation, but had no significant effect on bainite microstructure of HSLA steel. Welding heat input has a great impact on microstructure $[15,16]$. Yan Jin et al. found that the reaction zone between aluminum and oxygen in liquid steel was in a limited area within a fixed time. It produces less than $1 \mu \mathrm{m}$ spherical $\mathrm{Al}_{2} \mathrm{O}_{3}$ and the size is $0.1 \sim 1 \mu \mathrm{m}$ [17].

In addition to the characteristics of FCW, self-protective flux-cored wire (FCW-S) also reduces the weight of the welding gun, simplifies the structure and is easy to operate. It has good wind resistance and can weld smoothly under level 4 wind. The size requirements for assembly are not high. In this paper, the melting electrode self-protection is used for welding. Different contents of $\mathrm{Al}$ are added to the flux-cored wire. The effects of $\mathrm{Al}$ as a strong deoxidation and denitrification element combined with other elements on the microstructure and properties of WM of high-strength steel flux-cored wire are studied, and the toughening mechanism of high-strength WM is discussed, so as to provide a reference basis for the development of high-strength steel flux-cored wire.

\section{Materials and Methods}

Base metal used in the experiment is Q960 steel produced by Wuyang Iron and Steel Co., with a thickness of $12 \mathrm{~mm}$. Its main chemical composition and mechanical properties are shown in Table 1. Observed under an optical microscope, the microstructure of the base material is low-carbon martensite, containing a small amount of massive ferrite and pearlite, as shown in Figure 1.

Table 1. Chemical composition and mechanical properties of Q960 steel.

\begin{tabular}{|c|c|c|c|c|c|c|c|c|c|c|c|}
\hline \multicolumn{9}{|c|}{ Chemical Composition (Mass, wt $\%$ ) } & \multirow{2}{*}{$\begin{array}{c}\text { Tensile Strength } \\
\mathrm{Rm} / \mathrm{MPa}\end{array}$} & \multirow{2}{*}{ Elongation A/\% } & \multirow{2}{*}{$\begin{array}{l}\text { Impact Energy } \\
\text { Akv }\left(-20^{\circ} \mathrm{C}\right) / \mathrm{J}\end{array}$} \\
\hline $\mathrm{C}$ & Si & Mn & $\mathrm{Cr}$ & $\mathrm{Ni}$ & Mo & $\mathrm{Nb}$ & Ti & B & & & \\
\hline 0.18 & 0.5 & 1.6 & 0.8 & 1.0 & 0.6 & 0.05 & 0.03 & 0.005 & $\geq 960$ & $>12$ & $\geq 30$ \\
\hline
\end{tabular}

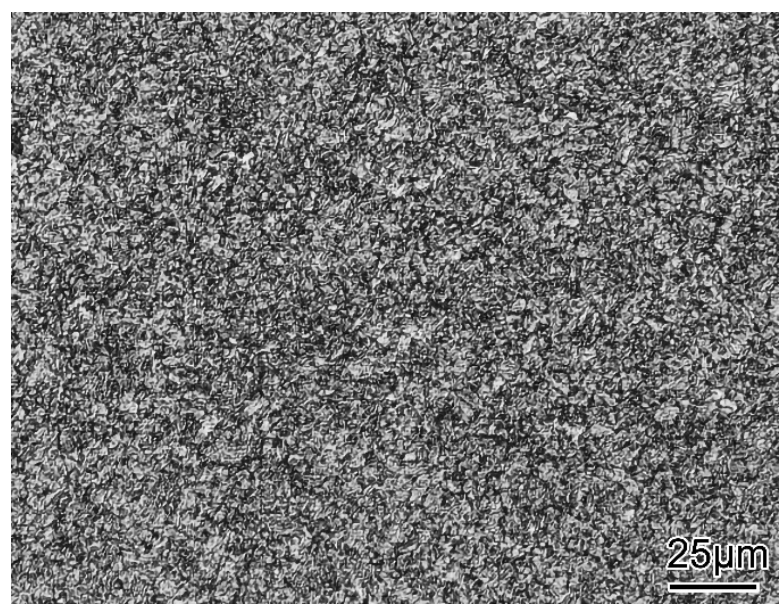

Figure 1. Microstructure morphology of Q960 steel.

Flux-cored wire is self-developed, which is prepared by the steel-strip-forming method, with a diameter of $1.6 \mathrm{~mm}$. The steel strip of flux-cored wire is SPCC steel produced by Baosteel, and the brand is H08A. The metal powder for producing the FCW includes ferrosilicon, aluminum, electrolytic manganese, nickel, molybdenum, chromium, titanium, 
boron iron and iron, with a particle size of 100 mesh. The composition is presented in Table 2.

Table 2. Mass fraction of test powder (mass, wt\%).

\begin{tabular}{cccccccccc}
\hline Ingredients & $\mathbf{M n}$ & $\mathbf{N i}$ & $\mathbf{M o}$ & $\mathbf{C r}$ & $\mathbf{T i}$ & $\mathrm{Al}$ & $\mathbf{B}$ & $\mathbf{F e}$ & $\mathbf{Z r}$ \\
\hline purity & $>99$ & 99.5 & 99.9 & 99.5 & 99.99 & 99.99 & $>19.5$ & 99.5 & 99 \\
\hline
\end{tabular}

The welding process parameters are shown in Table 3. When assembling before welding, place the two test plates in the butt position of the flat plate, and polish and clean both sides of the weld to remove oxide scale, rust, oil and so on. The semiautomatic wire feeder shall feed the wire vertically to the steel plate to ensure that the wire feeding speed is the same during each test. The flat welding position shall be welded, the extension length of the welding wire shall be 15 20 $\mathrm{mm}$ and the arc distance shall be $10 \mathrm{~mm}$. Self-shielded welding, a total of 5 layers and 7 welds, take samples according to the standard Tubular Cored Electrodes for Creep-resisting Steels (GB/T 17493-2018), as shown in Figure 2.

Table 3. Welding process parameters.

\begin{tabular}{ccccccc}
\hline Number & $\begin{array}{c}\text { Welding } \\
\text { Current I/A }\end{array}$ & $\begin{array}{c}\text { Welding } \\
\text { Voltage U/V }\end{array}$ & $\begin{array}{c}\text { Wire Feeding } \\
\text { Speed } \mathbf{~} / \mathbf{m i n}\end{array}$ & $\begin{array}{c}\text { Welding Speed } \\
\mathbf{~ m m} / \mathbf{m i n}\end{array}$ & $\begin{array}{c}\text { Extension } \\
\text { Length L/mm }\end{array}$ & $\begin{array}{c}\text { Interlayer } \\
\text { Temperature/ }{ }^{\circ} \mathbf{C}\end{array}$ \\
\hline Playing & $200 \sim 250$ & $28 \sim 30$ & 2 & 230 & $18 \sim 20$ & $150 \pm 10$ \\
Middle & $250 \sim 300$ & $30 \sim 32$ & 2 & 230 & $18 \sim 20$ & $150 \pm 10$ \\
Cover & $200 \sim 250$ & $28 \sim 30$ & 2 & 230 & $18 \sim 20$ & $150 \pm 10$ \\
\hline
\end{tabular}
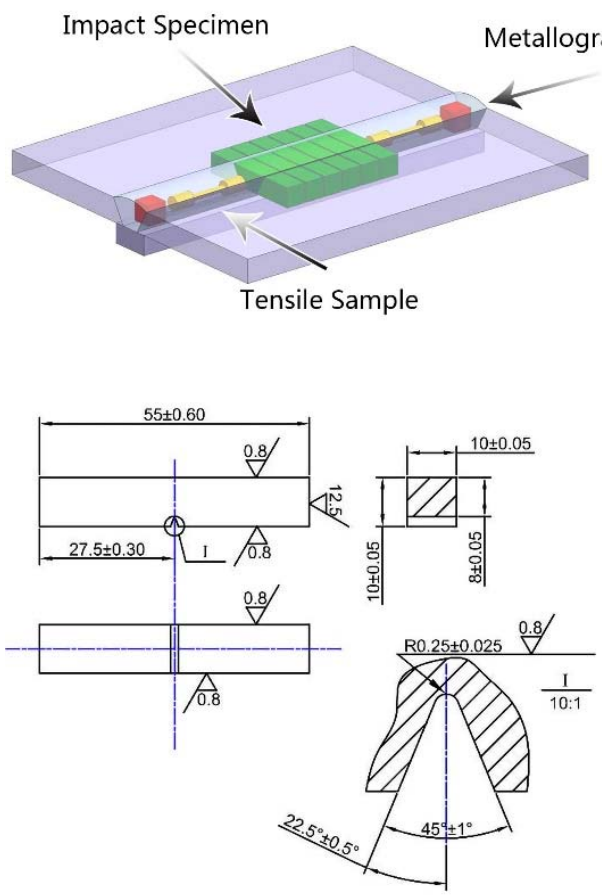

Unit : $\mathrm{mm}$

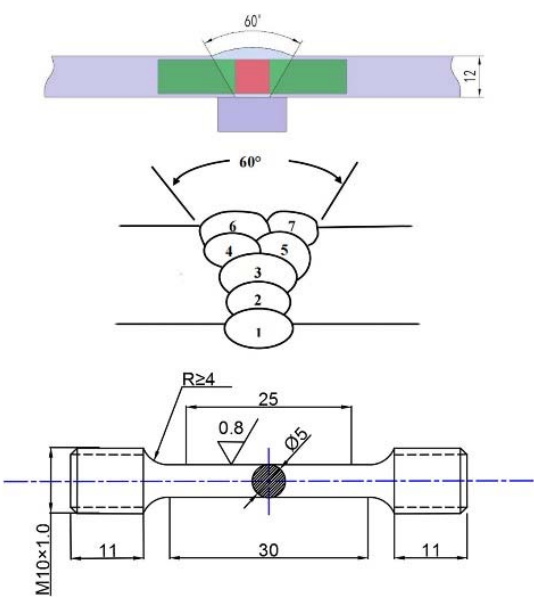

Figure 2. Welding diagram and sampling diagram.

Use YD-500 welding machine. Use infrared-temperature-measuring gun to measure interlayer temperature. Select the optimal welding parameters and weld at the flat welding position. Drill a certain amount of metal chip powder on the weld metal surface with a drill, and then measure the alloy elements with ICP-AES. O and N contents in weld metal shall be detected by ON 900 Oxygen \& Nitrogen Analyzer, after etching with 4\% nitric acid alcohol solution. The microstructure of weld metal was observed on Olympus GX-51. The inclusion size was counted by Image-Pro Plus. The fracture morphology 
was observed on Hitachi S-3400N scanning electron microscope, and the inclusions were analyzed by Hitachi S-3400N energy spectrum; the composition of alloy elements in weld metal was determined by chemical analysis. Conduct tensile test was performed according to Tensile Test Methods on Weld and Deposited Metal (GB/T 2652-2008). The tensile test was carried out on the GNT 200 electronic universal testing machine to measure the tensile strength, yield strength and elongation, and take the average value of 5 samples for each component. Conduct impact test was performed according to Impact Test Methods on Welded Joints (GB/T 2650-2008). The impact test is carried out on JB-30B impact testing machine, and the temperature is room temperature $\left(25^{\circ} \mathrm{C}\right), 0{ }^{\circ} \mathrm{C},-20^{\circ} \mathrm{C},-40{ }^{\circ} \mathrm{C}$ and $-60{ }^{\circ} \mathrm{C}$, and the average value of three samples shall be taken for each component. During the low-temperature impact test, put the sample into the low-temperature environment of $0{ }^{\circ} \mathrm{C} \sim-60{ }^{\circ} \mathrm{C}$ for $15 \sim 20 \mathrm{~min}$, take it out and quickly put it into the impact tester to complete the test; the instantaneous pendulum speed is $5 \mathrm{~m} / \mathrm{s}$. Charpy V-notch is used for impact test, and its position is the weld center. Figure 3 shows the impact test specimen and tensile test specimen of weld metal.

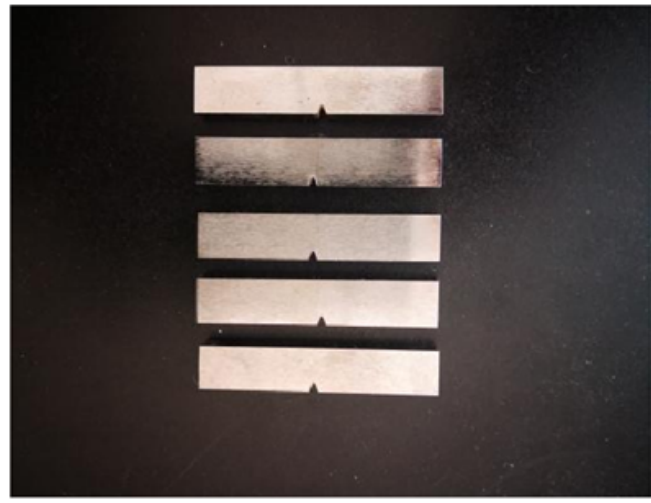

(a)

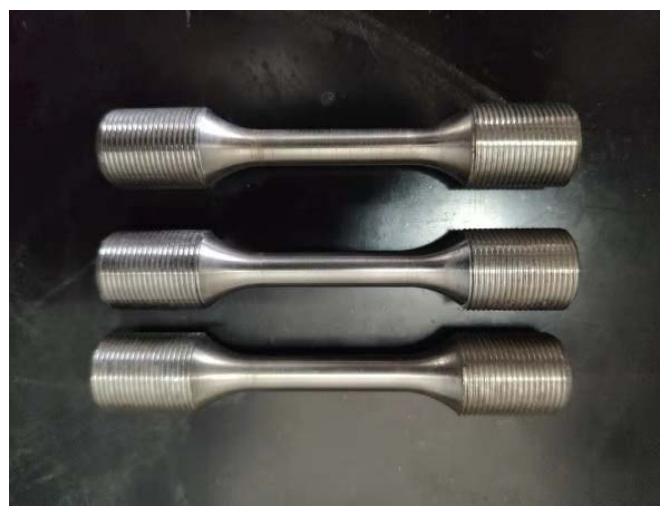

(c)

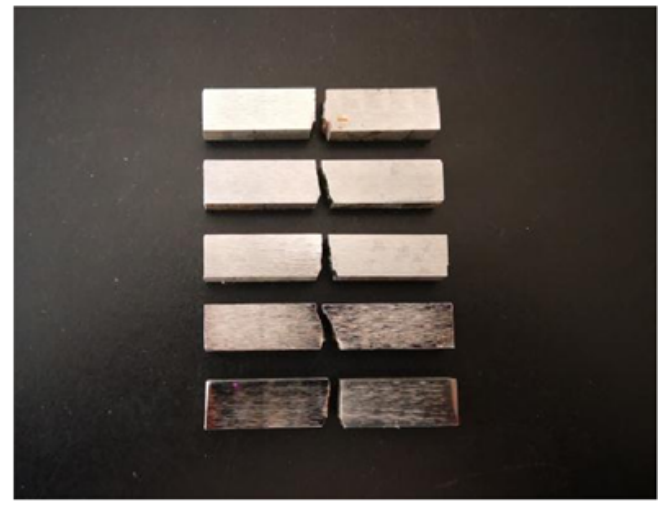

(b)

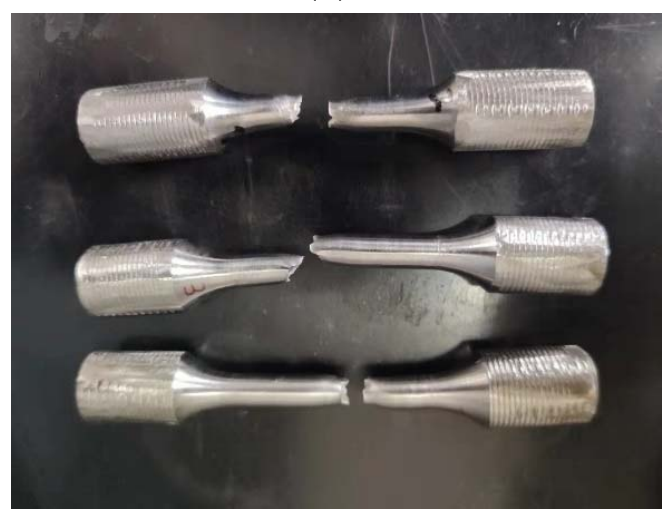

(d)

Figure 3. Impact test specimen and tensile test specimen of weld metal. (a) No impact. (b) After impact. (c) No stretched. (d) After stretched.

\section{Results}

Table 4 shows the content of alloy elements in WM. With the increase of Al content, the content of $\mathrm{Mn}$ increases, the content of $\mathrm{O}$ and $\mathrm{N}$ decreases and the content of other alloy elements has little change.

Figure 4 shows that with deoxidation and denitrification of $\mathrm{Al}$, the number of pores in weld metal also shows a downward trend. At the same time, the participation of $\mathrm{Al}$ in deoxidation and denitrification helps to reduce the content of $\mathrm{Al}$ in WM and improve the impact toughness. 
Table 4. Chemical composition of weld metal (mass, wt\%).

\begin{tabular}{ccccccccccc}
\hline Mn & Mo & $\mathbf{C r}$ & $\mathbf{N i}$ & $\mathbf{N b}$ & $\mathbf{T i}$ & $\mathbf{Z r}$ & $\mathbf{A l}$ & $\mathbf{O}$ & $\mathbf{N}$ \\
\hline 1.09 & 1.40 & 0.89 & 1.19 & 0.05 & 0.43 & 0.006 & 0 & 0.016 & 0.028 \\
1.14 & 1.43 & 0.90 & 1.18 & 0.06 & 0.45 & 0.006 & 0.21 & 0.016 & 0.019 \\
1.20 & 1.43 & 0.90 & 1.19 & 0.05 & 0.42 & 0.005 & 0.38 & 0.015 & 0.020 \\
1.21 & 1.42 & 0.90 & 1.20 & 0.06 & 0.43 & 0.006 & 0.62 & 0.010 & 0.017 \\
1.20 & 1.45 & 0.88 & 1.20 & 0.05 & 0.43 & 0.006 & 0.81 & 0.007 & 0.014 \\
1.22 & 1.41 & 0.90 & 1.20 & 0.07 & 0.40 & 0.006 & 1.05 & 0.005 & 0.010 \\
\hline
\end{tabular}

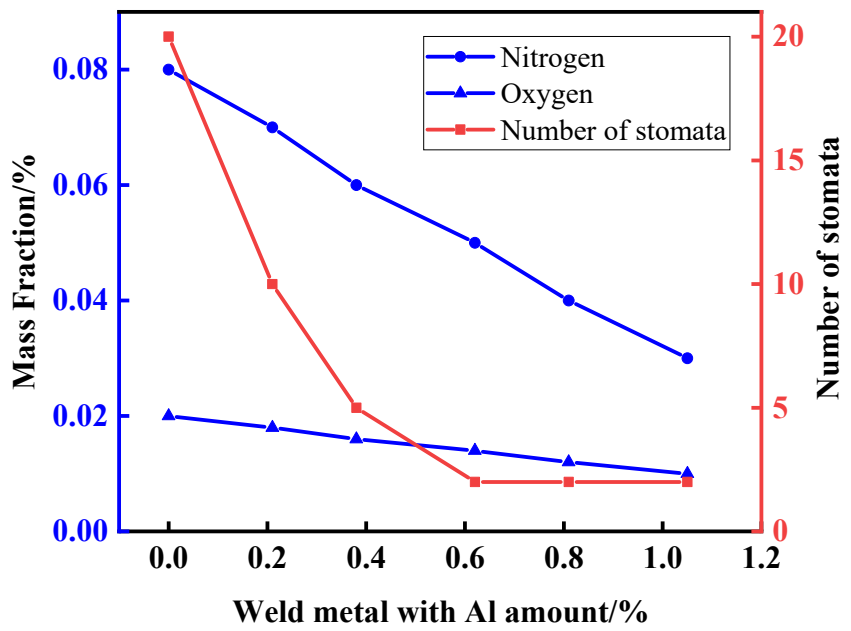

Figure 4. Effect of $\mathrm{Al}$ on oxygen and nitrogen content and porosity sensitivity of weld metal.

Figure 5 shows the effect of Al content change on weld metal structure. In Figure 5a, when the $\mathrm{Al}$ element is not added to the WM, the structure is composed of grain boundary ferrite, AF and a small amount of granular bainite. In Figure 5b,c, when the Al element content is low, the weld metal microstructure is proeutectoid ferrite, AF, pearlite and bainite. Continue to increase the content of $\mathrm{Al}$ element, and coarse skeleton structure appears in the weld metal. In Figure 5d-f, it is considered to be ferrite structure after analysis. In Figure 6, with the increase of aluminum content, the Vickers hardness of weld metal also increases.

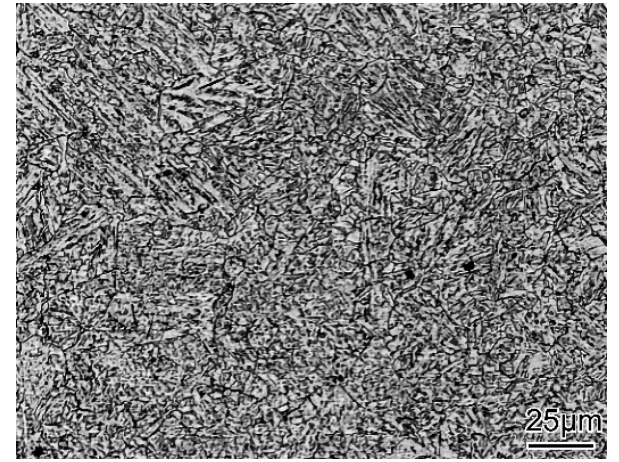

(a)

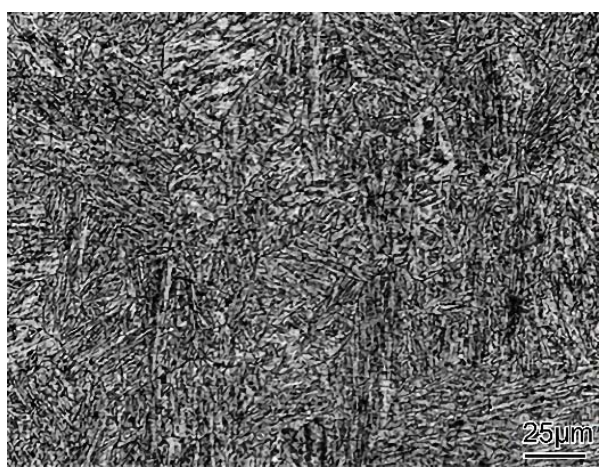

(b)

Figure 5. Cont. 


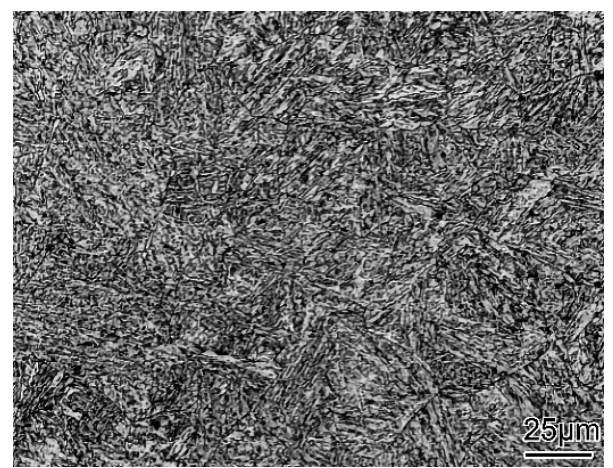

(c)

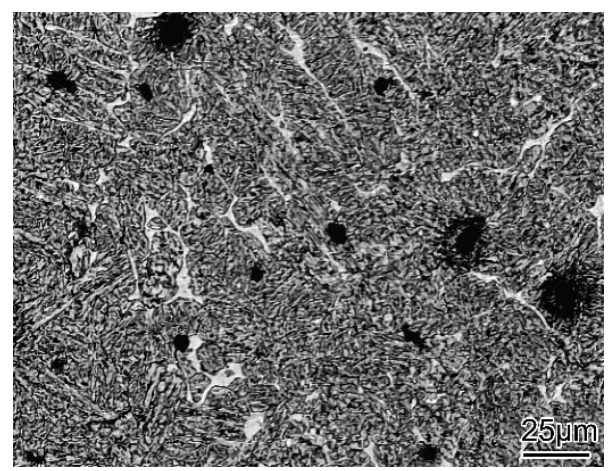

(e)

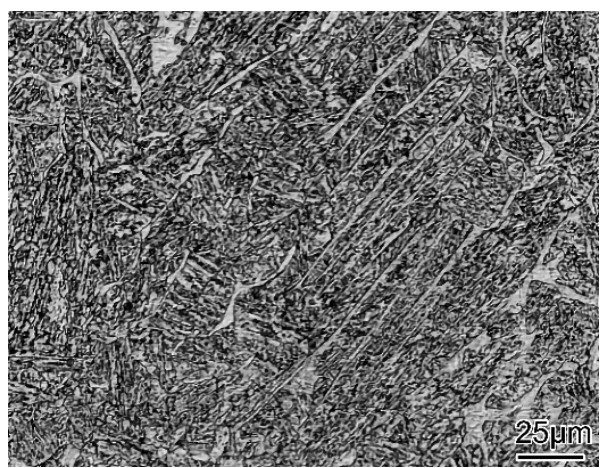

(d)

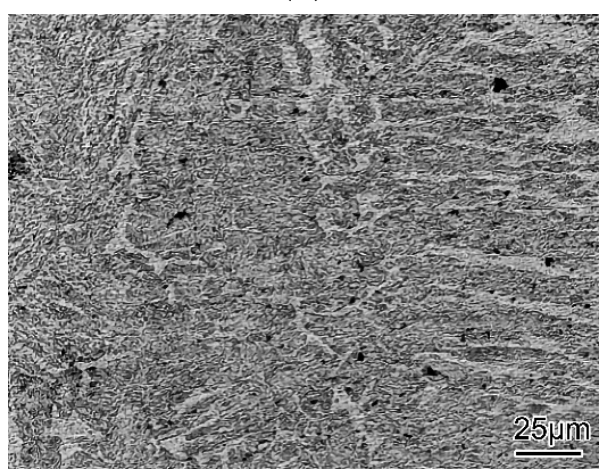

(f)

Figure 5. Effect of $\mathrm{Al}$ content on microstructure morphology of weld metal: (a) $0 \% \mathrm{Al}$; (b) $0.21 \% \mathrm{Al}$; (c) $0.38 \% \mathrm{Al}$; (d) $0.62 \% \mathrm{Al}$; (e) $0.81 \% \mathrm{Al}$; (f) $1.05 \% \mathrm{Al}$.

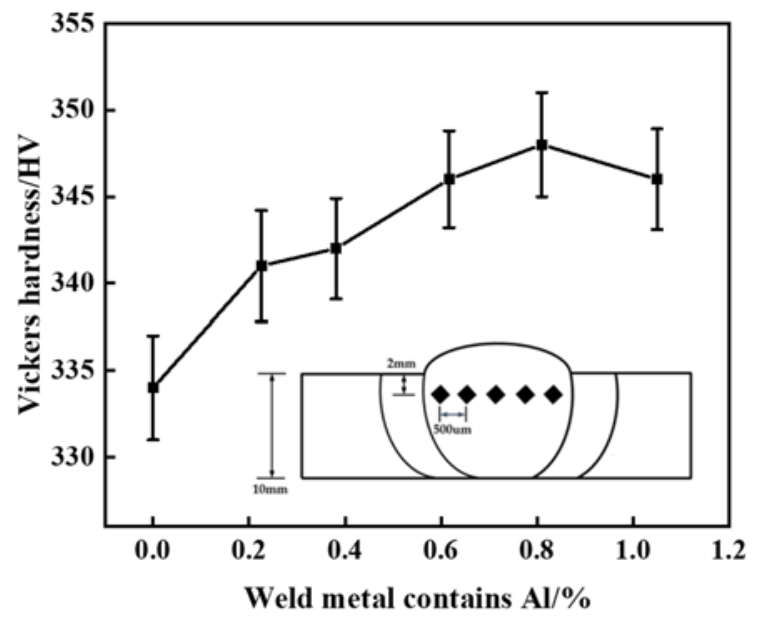

Figure 6. Effect of Al content on Vickers hardness of weld metal.

As shown in Figure 7, take metallographic samples of $0.21 \%$ Al weld metal and 1.05\% Al weld metal and observe them directly under the microscope with no etching after grinding. When the weld metal contains $0.21 \% \mathrm{Al}$, the inclusion particles are small and spherical; when the weld metal contains $1.05 \% \mathrm{Al}$, the inclusion particles in the weld metal are large and have polygonal structure. Energy spectrum analysis shows that most inclusions in $0.21 \% \mathrm{Al}$ are $\mathrm{Al}_{2} \mathrm{O}_{3}$, while the large particle inclusions in $1.05 \% \mathrm{Al}$ weld metal are AlN. 


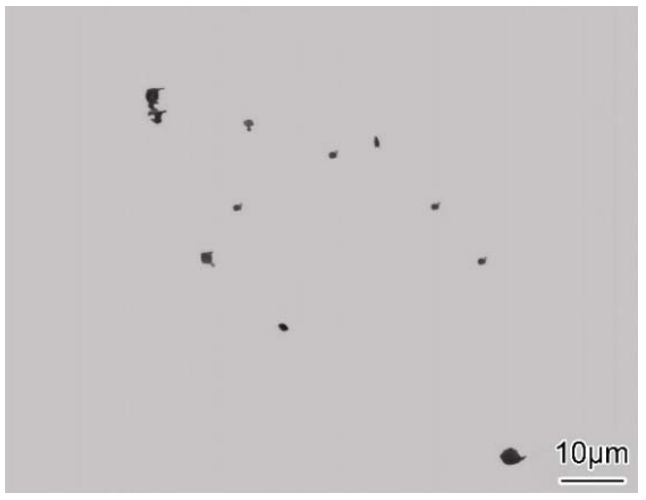

(a)

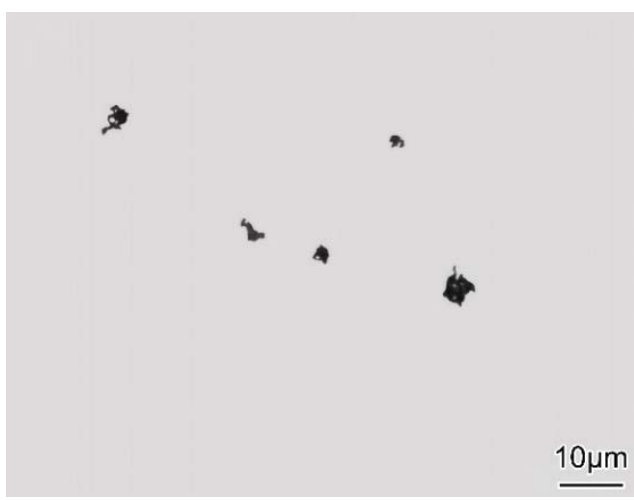

(c)

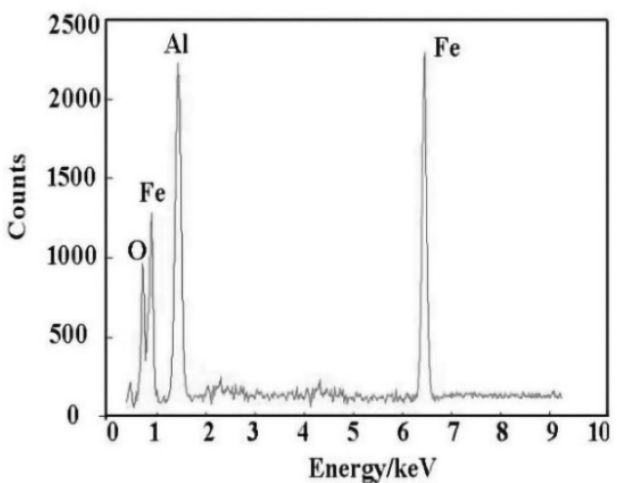

(b)

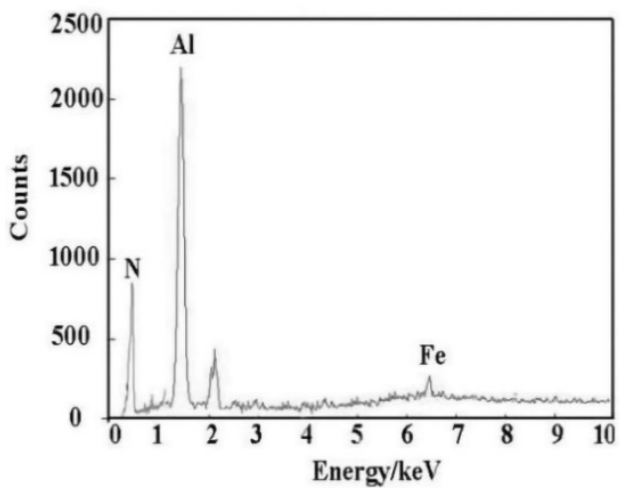

(d)

Figure 7. Morphology and energy spectrum analysis of inclusions: (a) $0.21 \% \mathrm{Al}$; (b) $\mathrm{Al}_{2} \mathrm{O}_{3}$ energy spectrum; (c) 1.05\%Al; (d) AlN energy spectrum.

Table 5 shows the statistics of inclusion size. It can be seen that when the content of $\mathrm{Al}$ is $0.21 \%$, the size of most inclusions is less than $1.0 \mu \mathrm{m}$. When the $\mathrm{Al}$ content is $1.05 \%$, the content in weld metal greater than $2.0 \mu \mathrm{m}$ inclusions increases and the number of microinclusions decreases significantly.

Table 5. Size distribution of inclusion in weld metal (number).

\begin{tabular}{ccccc}
\hline Al Element Content/\% & $<\mathbf{0 . 5} \boldsymbol{\mu m}$ & $\mathbf{0 . 5} \mathbf{1 . 0} \boldsymbol{\mu m}$ & $\mathbf{1 . 0} \mathbf{2 . 0} \boldsymbol{\mu m}$ & $>\mathbf{2 . 0} \boldsymbol{\mu m}$ \\
\hline 0.21 & 107 & 135 & 8 & 5 \\
1.05 & 99 & 76 & 6 & 12 \\
\hline
\end{tabular}

The tensile properties of welded joints are shown in Figure 8 . When the aluminum content is $0.21 \%$, the tensile performance of the joint is the best. With the increase of aluminum content, the tensile strength of the welded joint decreases slightly.

Figure 9 shows the effect of $\mathrm{Al}$ content change on the impact energy at $25^{\circ} \mathrm{C} \sim-60^{\circ} \mathrm{C}$. The optimum value appears at $0.21 \% \mathrm{Al}$. With the continuous increase of $\mathrm{Al}$ content, the impact energy decreases at room temperature or $0{ }^{\circ} \mathrm{C} \sim-60^{\circ} \mathrm{C}$. 


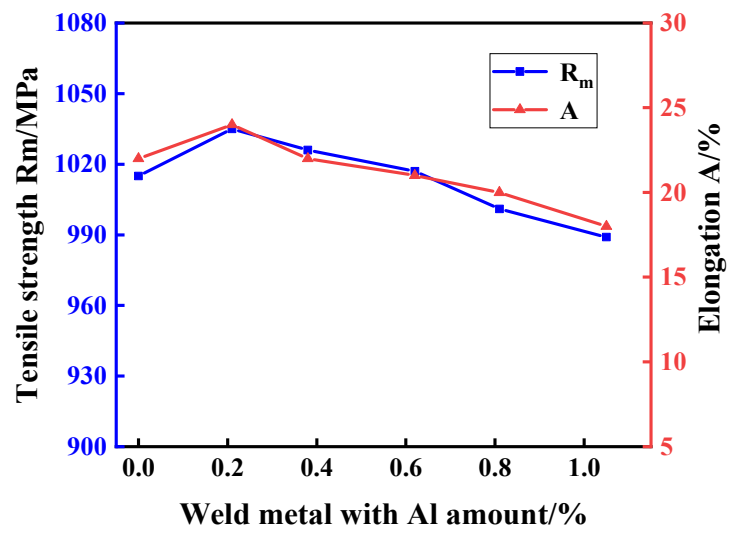

Figure 8. Effect of Al content on tensile properties of weld metal.

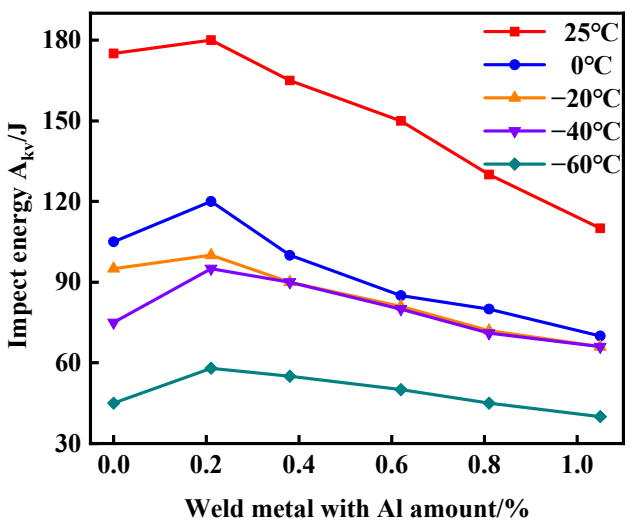

Figure 9. Effect of Al content on impact energy of weld metal.

\section{Discussion}

$\mathrm{O}$ and $\mathrm{N}$ in self-shielded flux-cored wire have an important influence on the formation of weld porosity. Moreover, some studies hypothesize that the weld porosity in selfshielded flux-cored wire is not only a simple $\mathrm{N}_{2}$ porosity or $\mathrm{CO}$ porosity, but also a kind of porosity containing both individual $\mathrm{N}_{2}$ porosity and $\mathrm{CO}$ porosity, as well as mixed $\mathrm{N}_{2}$ and $\mathrm{CO}$ porosity [18]. In the stage of droplet formation and droplet transition, $\mathrm{Al}$ in the weld metal mainly deoxidizes the pores of the weld metal in advance. Its action mechanism mainly has three aspects. First, $\mathrm{Al}$ is a strong deoxidizer with strong affinity with $\mathrm{O}$. Its deoxidation ability is ahead of $\mathrm{Ti}, \mathrm{C}, \mathrm{Mg}$ and $\mathrm{Zr}$. The oxidation potential of arc atmosphere can be reduced by early deoxidation. Second, $\mathrm{Al}$ can reduce the partial pressure of $\mathrm{NO}$ in the atmosphere while reducing the oxidation potential of arc atmosphere, so as to reduce the amount of nitrogen melted into the molten pool. Third, Al can react with $\mathrm{N}$ in the molten pool to form nitride and directly enter the slag to reduce the nitrogen content in the weld metal. Therefore, the more $\mathrm{Al}$ content in the molten pool metal and the less $[\mathrm{O}]$ and $[\mathrm{N}]$, the lower the possibility of forming $\mathrm{N}_{2}, \mathrm{CO}$ and their mixed pores.

$\mathrm{Al}$ entering the molten pool still maintains a strong deoxidation ability and can react with the oxide in the molten pool. Part of the oxide $\left[\mathrm{Al}_{2} \mathrm{O}_{3}\right]$ formed by it enters the slag and is excluded from the weld, and part remains in the weld metal to form microinclusions. $\mathrm{Al}$ in the molten pool also reacts with $\mathrm{N}$ in the molten pool to cause free $\mathrm{N}$ to form nitride and play the role of nitrogen fixation.

As a common deoxidation and denitrification element in weld metal, $\mathrm{Al}$ has an important impact on weld microstructure, inclusions and weld porosity. Formulas (1)-(4) show the relationship between deoxidation and nitrogen fixation reaction of $\mathrm{Al}$ element in weld metal and standard free energy formula. It can be seen that the affinity between $\mathrm{Al}$ and $\mathrm{O}$ in weld metal is much greater than that of other elements. Therefore, when there 
is $\mathrm{Al}$ in the weld metal, deoxidation reaction will take place preferentially, and nitrogen fixation reaction will take place when there is sufficient $\mathrm{Al}$.

$$
\begin{gathered}
2[\mathrm{Al}]+2[\mathrm{O}]=\mathrm{Al}_{2} \mathrm{O}_{3} \\
\Delta \mathrm{G}^{0}=-1,219,050+394.13 \mathrm{~T} \\
{[\mathrm{Al}]+[\mathrm{N}]=\mathrm{AlN}} \\
\Delta \mathrm{G}^{0}=-267,170.84+119.42 \mathrm{~T}
\end{gathered}
$$

$\Delta \mathrm{G}^{0}$ is the change of standard free energy, and [Al], [N] and [AlN] are the concentrations of $\mathrm{Al}, \mathrm{N}$ and $\mathrm{AlN}$ in liquid metal, respectively. In the actual welding process, some of the oxides and nitrides formed by $\mathrm{Al}$ will enter into the slag and be excluded from the weld metal, and some of them will enter into the weld metal and become inclusions.

With the increase of aluminum content, as shown in Figure $5 b, c$, when the $\mathrm{Al}$ content of weld metal is low, the molten pool metal precipitates first during solidification of $\delta$ ferrite; further cooling process, austenite along $\delta$-ferrite and liquid nucleation grow to both sides and peritectic reaction occurs. After the peritectic reaction, the liquid in the molten pool is consumed and the remaining $\delta$-ferrite forms austenite through isomeric transformation in the subsequent process. When cooling continues, eutectic transformation occurs; $\alpha$-ferrite precipitates from austenite to form eutectoid ferrite, discharges excess $C$, and then forms a certain amount of intragranular acicular ferrite, pearlite and other bainite structures. Continue to increase the aluminum content, and the weld metal appears as a coarse skeleton structure, as shown in Figure $5 d-f$, which is analyzed as ferrite structure. This is because $\mathrm{Al}$ is a strong ferrite-forming element, which can expand the ferrite-forming phase region and narrow the austenite phase region. When there is more $\mathrm{Al}$ in the weld metal, it first precipitates from the liquid metal during the solidification and cooling of the weld metal $\delta$-ferrite structure due to the solid solution of a large number of $\mathrm{Al}$ elements in the weld metal, reduces the austenite phase zone, hinders the formation of austenite and makes it so the formation of ferrite cannot be completely transformed into austenite in the subsequent cooling process, but remains in the weld metal structure in a coarse skeleton shape, which has an adverse impact on the mechanical properties of the weld metal [19]. The change of hardness is consistent with the change of microstructure and chemical composition, as shown in Figure 6. When aluminum is added to the weld metal, the hardness value shows an upward trend. At $0.21 \% \mathrm{Al}$, the best hardness value and microstructure were obtained. At more than $0.21 \% \mathrm{Al}$, on the one hand, hard and brittle coarse ferrite structure is produced. On the other hand, the addition of aluminum leads to the increase of manganese. Manganese is a solid strengthening element, which can affect the transformation of austenite and will increase the hardness.

In the weld metal, $\mathrm{Al}$ easily reacts with $\mathrm{O}$ to form $\mathrm{Al}_{2} \mathrm{O}_{3}$ microinclusions, which have a spherical shape with a size of less than $1 \mu \mathrm{m}$, as shown in Figure 7. The microinclusions dominated by $\mathrm{Al}_{2} \mathrm{O}_{3}$ are conducive to the nucleation of $\mathrm{AF}$ in the weld metal. Because the inclusions are high-energy inert interfaces, they can reduce the potential barrier of acicular ferrite nucleation [20]. The expansion coefficients of inclusions and weld metal matrix are different, and the formed high-stress zone can promote the nucleation of acicular ferrite, as shown in Figure 10. In addition, there is a small lattice dislocation between microinclusions and ferrite, which reduces the interface energy and is conducive to the nucleation of AF. When the Al content of weld metal increases, as shown in Figure 7c, more AlN inclusions are formed, which are polygonal structures with edges and corners, while the number of spherical $\mathrm{Al}_{2} \mathrm{O}_{3}$ inclusions decreases, resulting in the reduction of WM impact energy and tensile strength. In the welding process of HSLA steel, the dissolution of $\mathrm{N}$ in the molten pool should be strictly controlled, so as to reduce the formation of AlN inclusions in the weld metal and improve the impact toughness of flux-cored wire [21]. The improvement of impact energy and tensile strength of weld metal is mainly related to the size, distribution and shape of inclusions in weld metal and the change of microstructure of weld metal. For 
example, polygonal inclusions in weld metal are more harmful than circular inclusions; larger inclusions are more harmful than smaller ones. The formation of coarse, brittle and hard ferrite will also endanger the impact energy.

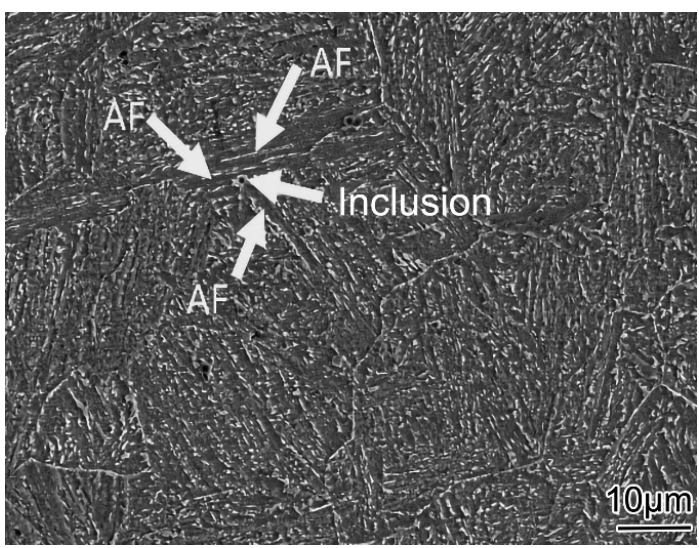

Figure 10. Nucleation of acicular ferrite.

Figure 11 is an SEM photograph of a tensile fracture of $0.21 \% \mathrm{Al}, 0.62 \% \mathrm{Al}$ and $1.05 \%$ $\mathrm{Al}$ welds. From the tensile fracture of weld metal, it can be seen that they are equiaxed dimples. When it contains $0.21 \% \mathrm{Al}$, the number of second phase particles is large, the fracture morphology is mainly small dimples and the dimple depth is deep. It can be seen that there are fine inclusions in most dimples. When the $\mathrm{Al}$ content is $0.62 \%$, the tensile fracture morphology mainly distributes small dimples around the large dimples, the dimple depth is shallow and there are tearing edges. When the weld metal contains $1.05 \% \mathrm{Al}$, the dimple is large and the dimple depth is very shallow. The fracture dimple depth is closely related to the plastic deformation ability of WM. When the weld metal plasticity is large, the dimple depth is deep. The size of the fracture dimple is related to the size and number of inclusions. The larger the inclusion size, the larger the dimple size. When the number of inclusions is small, the dimple size is large. This is consistent with the data in Table 5 and Figure 8.

Figure 12 is the impact fracture micromorphology of the central area of $0.21 \%$ and $1.05 \% \mathrm{Al}$ weld metal in the impact test at $0{ }^{\circ} \mathrm{C}$ and $-60^{\circ} \mathrm{C}$. According to the dimple parabola, the direction of shear stress is to the right during fracture. At $0{ }^{\circ} \mathrm{C}$, the impact fracture containing $0.21 \% \mathrm{Al}$ is a ductile fracture, with large and deep dimples. With the aluminum content, the dimple of impact fracture becomes shallower and smaller. At $-60^{\circ} \mathrm{C}$, part of the impact fracture of $0.21 \% \mathrm{Al}$ is dimple, the other part is cleavage fracture, and there are obvious tear edges. The impact fracture of $1.05 \% \mathrm{Al}$ is cleavage fracture, typical brittle fan-shaped cleavage fracture, accompanied by multiple tear edges. With the Al element content in the WM, the content of acicular ferrite in the structure increases. Because the AF structure is a large-angle grain boundary and has high-density dislocations, it hinders the propagation of microcracks, so the impact energy of the weld metal is improved. The $\mathrm{Al}$ content reaches and exceeds $0.21 \%$ and the impact energy decreases rapidly. This is because AlN and $\mathrm{Al}_{2} \mathrm{O}_{3}$ are brittle inclusions in the weld metal. Due to the different deformation capacity between the inclusions and the weld matrix, stress concentration is bound to occur at the junction, resulting in microcracks. In the weld metal, the stress required for microcrack initiation is directly proportional to the inclusion diameter $\mathrm{d}^{-1 / 2}$ [22]. Therefore, large particle inclusions will preferentially form micropores in the weld metal, so as to reduce the impact energy of the weld metal. As mentioned earlier, when the Al content in the weld metal exceeds $0.21 \%$, the weld metal more easily forms a size greater than $1 \mu \mathrm{m}$. The existence of these large-size inclusions reduces the impact energy of weld metal. In addition, when the Al content of weld metal increases, more AlN inclusions are formed, which are polygonal structures with edges and corners, while the number of spherical 
$\mathrm{Al}_{2} \mathrm{O}_{3}$ inclusions decreases, which is also one of the reasons for the reduction of impact energy of weld metal.

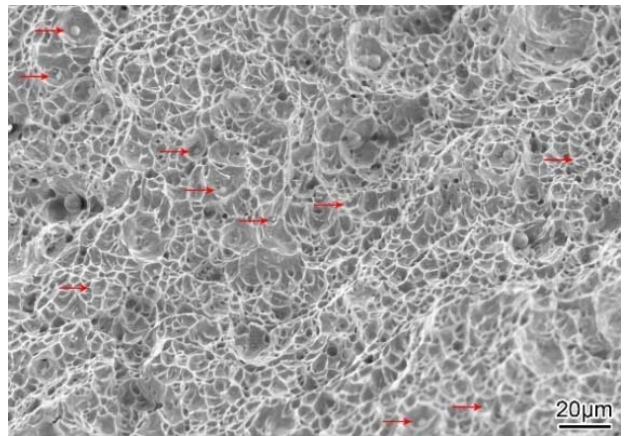

(a)

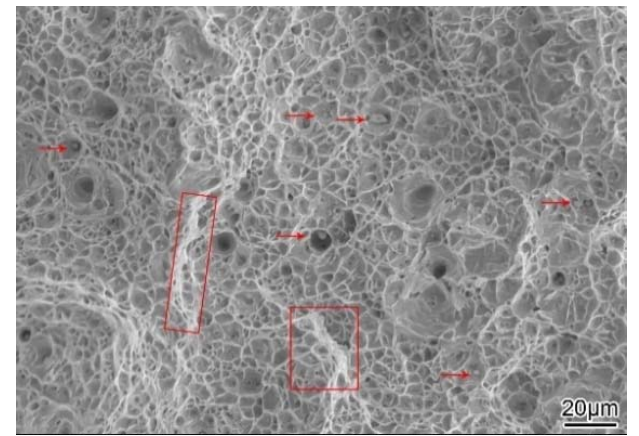

(b)

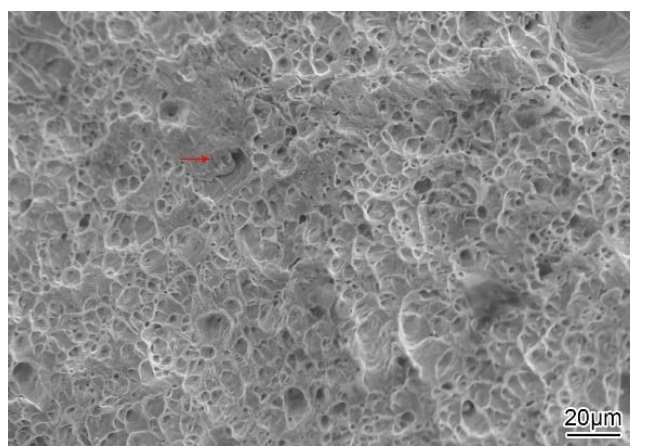

(c)

Figure 11. Morphology of tensile fracture of weld metal: (a) $0.21 \% \mathrm{Al}$; (b) $0.62 \% \mathrm{Al}$; (c) $1.05 \% \mathrm{Al}$.

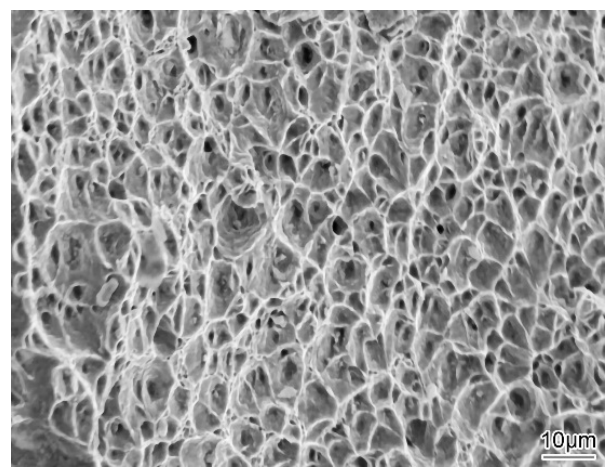

(a)

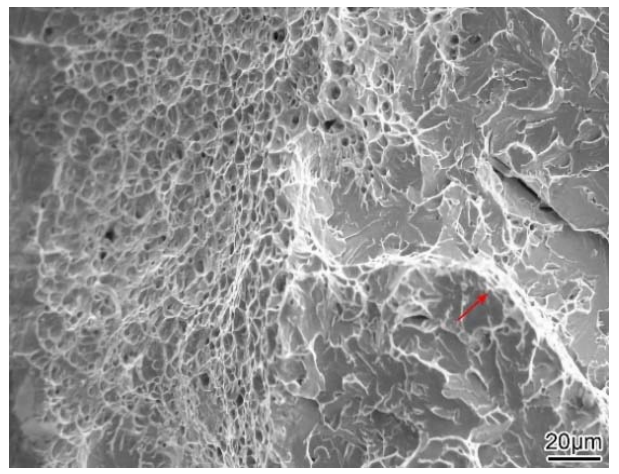

(c)

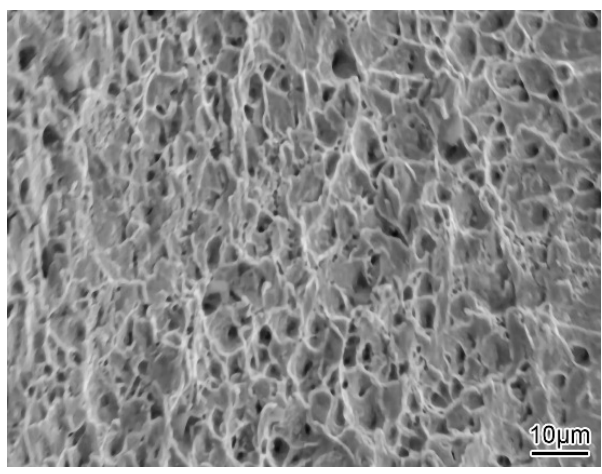

(b)

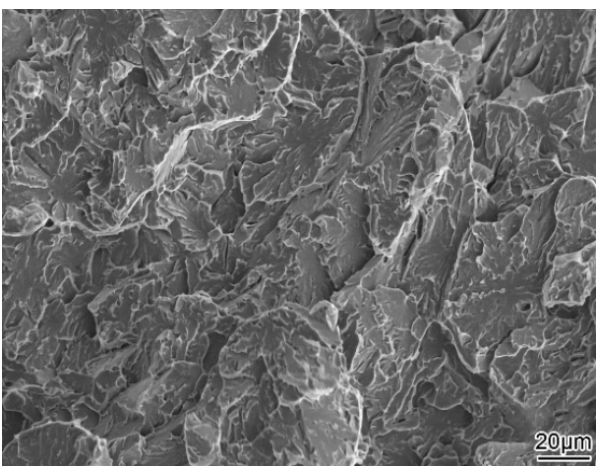

(d)

Figure 12. Morphology of impact fracture of weld metal: (a) $0.21 \% \mathrm{Al}$ at $0{ }^{\circ} \mathrm{C} ;(\mathbf{b}) 1.05 \% \mathrm{Al}$ at $0{ }^{\circ} \mathrm{C}$; (c) $1.05 \% \mathrm{Al}$ at $-60{ }^{\circ} \mathrm{C}$; (d) $1.05 \% \mathrm{Al}$ at $-60{ }^{\circ} \mathrm{C}$. 


\section{Conclusions}

The effect of $\mathrm{Al}$ addition on the microstructure and properties of weld metal of HSLA steel was studied. According to the results, the following conclusions are drawn.

(1) The increase of $\mathrm{Al}$ content reduces the content of $\mathrm{O}$ and $\mathrm{N}$, which reflects the strong ability of deoxidation and denitrification. In the stage of droplet formation and droplet transition, $\mathrm{Al}$ mainly deoxidizes the pores of the WM in advance, and the $\mathrm{Al}$ entering the molten pool still maintains a strong deoxidation ability. With deoxidation and denitrification of $\mathrm{Al}$, the number of pores in weld metal also shows a downward trend, which improves the strength of WM and low-temperature impact toughness.

(2) When the content of $\mathrm{Al}$ element is low, $\mathrm{Al}_{2} \mathrm{O}_{3}$ oxide inclusions are easily formed in the structure; they are round and small in size. They are dispersed and can become AF nucleation and mass points, which is conducive to improving the impact energy absorption of the weld metal and the impact toughness of flux-cored wire. When the content of $\mathrm{Al}$ is high, AlN nitride is formed in the structure, with large particles and polygon that easily produce microcracks between the inclusions and the surrounding matrix, which has an adverse impact on the impact energy absorption of the weld metal.

(3) With the increase of $\mathrm{Al}$ content in weld metal, the tensile properties and lowtemperature impact properties first increase and then decrease. The best value appears at $0.21 \% \mathrm{Al}$, the tensile strength reaches $1035 \mathrm{mpa}$, the impact energy at $0{ }^{\circ} \mathrm{C}$ reaches $180 \mathrm{~J}$ and the low-temperature impact energy at $-60{ }^{\circ} \mathrm{C}$ is $58 \mathrm{~J}$. When the $\mathrm{Al}$ content is $0.21 \%$, most of the dimensions are $1.0 \mu \mathrm{m}$. With the increase of acicular ferrite content in the microstructure, the tensile properties and impact properties are optimized.

Author Contributions: Conceptualization, Z.Z. and Z.L.; methodology, X.A.; software, D.W.; data curation, Z.Z.; writing—original draft preparation, Z.Z.; writing—review and editing, Z.Z. All authors have read and agreed to the published version of the manuscript.

Funding: This research received no external funding.

Informed Consent Statement: Informed consent was obtained from all subjects involved in the study.

Data Availability Statement: Data available in a publicly accessible repository.

Conflicts of Interest: The authors declare no conflict of interest.

\section{References}

1. Rodrigues, T.A.; Duarte, V.; Avila, J.A.; Santos, T.G.; Miranda, R.M.; Oliveira, J.P. Wire and arc additive manufacturing of HSLA steel: Effect of thermal cycles on microstructure and mechanical properties. Addit. Manuf. 2019, 27, 440-450. [CrossRef]

2. Ai, X.; Liu, Z.; Wu, D. Study on Improvement of Welding Technology and Toughening Mechanism of Zr on Weld Metal of Q960 Steel. Materials 2020, 13, 892. [CrossRef] [PubMed]

3. Shao, Y.; Liu, C.; Yan, Z.; Li, H.; Liu, Y. Formation mechanism and control methods of acicular ferrite in HSLA steels: A review. J. Mater. Sci. Technol. 2018, 34, 737-744. [CrossRef]

4. Li, Z.; Srivatsan, T.S.; Wang, Y.; Zhang, W.; Li, Y. The Spectral Analysis of Different Flux-Cored Wires during Arc Welding of Metals. Mater. Manuf. Processes 2012, 27, 664-669. [CrossRef]

5. Charleux, M.; Poole, W.J.; Militzer, M.; Deschamps, A. Precipitation behavior and its effect on strengthening of an HSLA-Nb/Ti steel. Metall. Mater. Trans. A 2001, 32, 1635-1647. [CrossRef]

6. $\quad$ Park, D.-B.; Huh, M.-Y.; Shim, J.-H.; Suh, J.-Y.; Lee, K.-H.; Jung, W.-S. Strengthening mechanism of hot rolled Ti and Nb microalloyed HSLA steels containing Mo and W with various coiling temperature. Mater. Sci. Eng. A 2013, 560, 528-534. [CrossRef]

7. Zhang, S.; Fan, E.; Wan, J.; Liu, J.; Huang, Y.; Li, X. Effect of Nb on the hydrogen-induced cracking of high-strength low-alloy steel. Corros. Sci. 2018, 139, 83-96. [CrossRef]

8. A-rong; Zhao, L.; Pan, C.; Tian, Z.-L. Influence of Ti on weld microstructure and mechanical properties in large heat input welding of high strength low alloy steels. J. Iron Steel Res. Int. 2015, 22, 431-437. [CrossRef]

9. Kang, Y.; Jang, J.; Park, J.H.; Lee, C. Influence of Ti on non-metallic inclusion formation and acicular ferrite nucleation in high-strength low-alloy steel weld metals. Met. Mater. Int. 2014, 20, 119-127. [CrossRef]

10. Beidokhti, B.; Koukabi, A.H.; Dolati, A. Effect of titanium addition on the microstructure and inclusion formation in submerged arc welded HSLA pipeline steel. J. Mater. Process. Technol. 2009, 209, 4027-4035. [CrossRef]

11. Babu, S.S. The mechanism of acicular ferrite in weld deposits. Curr. Opin. Solid State Mater. Sci. 2004, 8, 267-278. [CrossRef] 
12. Varshney, A.; Sangal, S.; Kundu, S.; Mondal, K. Super strong and highly ductile low alloy multiphase steels consisting of bainite, ferrite and retained austenite. Mater. Des. 2016, 95, 75-88. [CrossRef]

13. Díaz-Fuentes, M.; Iza-Mendia, A.; Gutiérrez, I. Analysis of different acicular ferrite microstructures in low-carbon steels by electron backscattered diffraction. Study of their toughness behavior. Metall. Mater. Trans. A 2003, 34, 2505-2516. [CrossRef]

14. Bhole, S.D.; Nemade, J.B.; Collins, L.; Liu, C. Effect of nickel and molybdenum additions on weld metal toughness in a submerged arc welded HSLA line-pipe steel. J. Mater. Process. Technol. 2006, 173, 92-100. [CrossRef]

15. Huang, G.; Wan, X.; Wu, K.; Zhao, H.; Misra, R.D.K. Effects of Small Ni Addition on the Microstructure and Toughness of Coarse-Grained Heat-Affected Zone of High-Strength Low-Alloy Steel. Metals 2018, 8, 718. [CrossRef]

16. Huang, G.; Wan, X.L.; Wu, K.M. Effect of Cr Content on Microstructure and Impact Toughness in the Simulated Coarse-Grained Heat-Affected Zone of High-Strength Low-Alloy Steels. Steel Res. Int. 2016, 87, 1426-1434. [CrossRef]

17. Jin, Y.; Liu, Z.; Takata, R. Nucleation and Growth of Alumina Inclusion in Early Stages of Deoxidation: Numerical Modeling. ISIJ Int. 2010, 50, 371-379. [CrossRef]

18. Arivazhagan, B.; Sundaresan, S.; Kamaraj, M. A study on influence of shielding gas composition on toughness of flux-cored arc weld of modified 9Cr-1Mo (P91) steel. J. Mater. Process. Technol. 2009, 209, 5245-5253. [CrossRef]

19. Ricks, R.A.; Howell, P.R.; Barritte, G.S. The nature of acicular ferrite in HSLA steel weld metals. J. Mater. Sci. 1982, 17, 732-740. [CrossRef]

20. Shim, J.H.; Byun, J.S.; Cho, Y.W.; Oh, Y.J.; Shim, J.D.; Lee, D.N. Effects of Si and Al on acicular ferrite formation in C-Mn steel. Met. Mater. Trans. A 2001, 32, 75-83. [CrossRef]

21. Sarma, D.S.; Karasev, A.V.; Jönsson, P.G. On the Role of Non-metallic Inclusions in the Nucleation of Acicular Ferrite in Steels. ISIJ Int. 2009, 49, 1063-1074. [CrossRef]

22. Kocatepe, K.; Cerah, M.; Erdogan, M. The tensile fracture behaviour of intercritically annealed and quenched plus tempered ferritic ductile iron with dual matrix structure. Mater. Des. 2007, 28, 172-181. [CrossRef] 